FRENCH FILM DIRECTORS
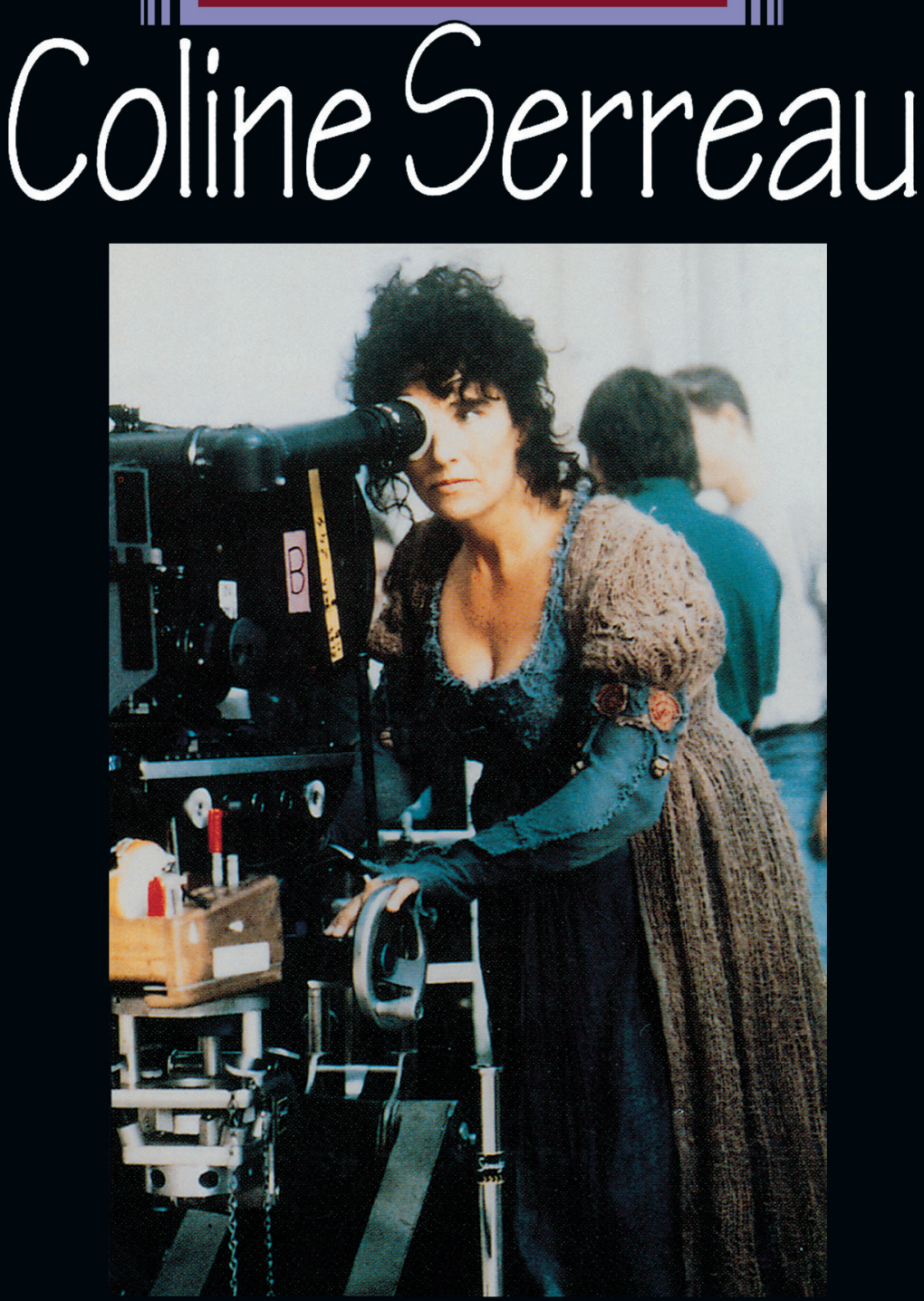

BRIGITTE ROLLET 


\section{Coline Serreau}

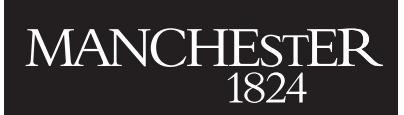

Manchester University Press 


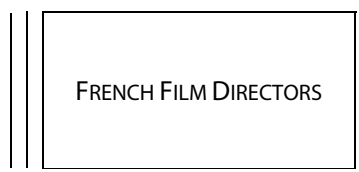

DIANA HOLMES and ROBERT INGRAM series editors

DUDLEY ANDREWS series consultant

Luc Besson SUSAN HAYWARD

Diane Kurys CARRIE TARR

François Truffaut DIANA HOLMES AND ROBERT INGRAM

Agnès Varda ALISON SMITH

forthcoming titles

Jean-Jacques Beineix PHIL POWRIE

Bertrand Blier SUE HARRIS

Robert Bresson KEITH READER

Claude Chabrol GUY AUSTIN

Jean-Luc Godard STEVE CANNON AND ELIANE MEYER

George Méliès ELIZABETH EZRA

Jean Renoir MARTIN O'SHAUGHNESSY

Eric Rohmer HOWARD DAVIES 


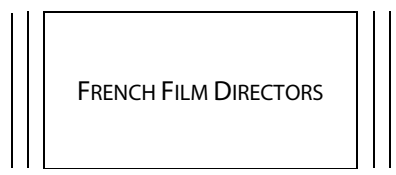

\section{Coline Serreau}

\section{BRIGITTE ROLLET}

Manchester University Press

Manchester 


\section{Copyright (C) Brigitte Rollet 1998}

The right of Brigitte Rollet to be identified as the author of this work has been asserted by her in accordance with the Copyright, Designs and Patents Act 1988.

Published by Manchester University Press

Altrincham Street, Manchester Ml 7JA, UK

www.manchesteruniversitypress.co.uk

British Library Cataloguing-in-Publication Data is available

Library of Congress Cataloging-in-Publication Data is available

ISBN 9780719050886 paperback

First published by Manchester University Press in 1998

The publisher has no responsibility for the persistence or accuracy of URLs for any external or third-party internet websites referred to in this book, and does not guarantee that any content on such websites is, or will remain, accurate or appropriate. 